\title{
Optimization of protein and tannin extraction in Moringa oleifera leaf as antioxidant source
}

\author{
1,*Wahyuni, R., ${ }^{2}$ Wignyanto, W., ${ }^{2}$ Wijana, S. and ${ }^{2}$ Sucipto, S. \\ ${ }^{1}$ Department Food Science and Technology, Faculty of Agriculture, Yudharta University, Purwosari, \\ Pasuruan, East Java, Indonesia \\ ${ }^{2}$ Department of Agro Industrial Technology, Faculty of Agricultural Technology, Brawijaya University, \\ Malang, East Java, Indonesia
}

\begin{abstract}
Article history:
Received: 23 June 2020

Received in revised form: 16

July 2020

Accepted: 9 August 2020

Available Online: 3 October 2020
\end{abstract}

Keywords:

Moringa leaf,

Extraction optimization,

Total protein,

Total tannin,

Antioxidant activity

DOI:

https://doi.org/10.26656/fr.2017.4(6).293

\begin{abstract}
Moringa oleifera contains high nutritional and bioactive compounds that have the potential as a source of antioxidants. The main objective of this study was to obtain optimal conditions in the extraction process of Moringa leaf, maintain protein and antioxidant activity, and reduce tannin. It is carried out through the response surface method which consists of two factors. The first factor $\left(\mathrm{X}_{1}\right)$ was the extraction temperature $\left({ }^{\circ} \mathrm{C}\right)$ which contains three levels, namely 70,80 , and $90^{\circ} \mathrm{C}$. The second factor $\left(\mathrm{X}_{2}\right)$ was time (mins) consisting of three levels, namely 5, 10, and 15 mins. The parameters in this study were total protein, antioxidant activity, and total tannin. The results revealed that the optimum condition for Moringa leaf extraction is found to be temperature $80.54^{\circ} \mathrm{C}$ and a time of 12.19 mins. In that treatment, the total protein is $17.4594 \%$, antioxidant activity is up to $10.2629 \mu \mathrm{g} / \mathrm{mL}$, and tannin is $7.853 \%$ with the desirability of 0.792 or $79.2 \%$.
\end{abstract}

\section{Introduction}

Moringa oleifera is a well famous plant cultivated in hot up to tropical climates, such as Indonesia (Mendieta et al., 2013). Organic moringa cultivation in Indonesia has been carried out in several regions such as Blora, Central Java, Gunung Kidul, Yogyakarta, Poteran Island, Sumenep Regency, and NTT Province. One of the parts of the moringa plant that can be utilized is the leaf, where the production of wet leaves is around 5-6 tons/ hectare (Krisnandi, 2015).

Moringa leaf contains fiber, protein, fat, minerals such as $\mathrm{Ca}, \mathrm{Mg}, \mathrm{P}, \mathrm{K}, \mathrm{Cu}, \mathrm{Fe}, \mathrm{S}$, Vitamins: A (Betacarotene), B-choline, B1-thiamine, riboflavin, nicotinic acid, ascorbic acid, acid Amino: Arginine, Lysin, Tryptophan, Phenylalanine, Threonine, Leucine, Methionine, Isoleucine, Valine, Phytochemicals: tannin, sterol, saponin, terpenoid, phenolic, alkaloid, flavonoid, quercetin, isoleucine, valine, phytochemicals: tannins, sterols, saponins, terpenoids, phenolics, alkaloids, flavonoids, quercetin, isoleucine, violins, phytochemicals: tannins, sterols, saponins, terpenoids, phenolics, alkaloids, flavonoids, quercetin, isoucercitins, caemferothosrays, glycothiocytes, glycotosicans (Gopalakrishnan et al., 2016). Besides, the iron content in moringa leaf is also higher than other vegetables, which is $17.2 \mathrm{mg} / 100 \mathrm{~g}$ (Yameogo et al., 2011).

In general, all parts in the moringa plant have several functions, namely as hypolipidemic, antiatherosclerotic, prevention of cardiovascular disease (Chumark et al., 2008), anti-diabetic, inflammation, anemia, and immune system booster because moringa is rich in nutrients, essential amino acids, vitamins, minerals, and 40 natural antioxidants sources (Mahmood et al., 2010).

Nowadays, most research on the use of moringa leaf tend to be directed to the use of natural antioxidants. The antioxidant activity of moringa leaf extract, both young and old, is very effective to prevent oxidative damage of the main biomolecules (Shahriar et al., 2012). This is because the phenol content in a leaf is much higher compared to pods and seeds, so the use of moringa leaf as a source of natural antioxidants is highly recommended (Wangcharoen et al., 2011). Apart from being a source of antioxidant, the leaf also has a function as anti-inflammatory, anti-pain (Upadhye et al., 2011), anti-ulcer (Das et al., 2011), and as an antimicrobial and wound healing (Moyo et al., 2012). In addition to its advantages, moringa has weaknesses, including having a low protein digestibility which is $56.1 \pm 8.9 \%$ and there are anti-nutritional substances namely tannins, saponins, and trypsin inhibitors. Production protein concentrates is 
one way to increase digestibility and reduce anti-nutrient properties in moringa leaf (Kholis and Hadi, 2010).

The anti-nutritional substances in moringa leaf can be reduced by heating the leaves in water (Ogbe and Affiku, 2011). Heat extraction treatment is one of the methods to produce protein concentrate from a leaf to create higher protein content compared to the raw materials (Purwitasari et al., 2014).

Taking into account the composition of chemical nutrients, the content of bioactive compounds, antioxidant compounds, and the presence of anti-nutrient substances in moringa leaf, it is necessary to conduct a research on how to use moringa leaf as a source of nutrition, especially as a protein source and natural antioxidants. Furthermore, in order not to damage the protein and bioactive sources of the antioxidants and reduce the tannin content, a simple method should be employed. The purpose of this study was to optimize the extraction conditions of moringa leaf to obtain a high protein with high antioxidant capacity and low tannin extraction.

\section{Materials and methods}

\subsection{Materials}

Materials used were fresh Moringa oleifera leaves obtained in Sekarmojo Village, Purwosari District, Pasuruan Regency, water as solvent, DPPH (1,1diphenyl-2-picrylhydrazyl), methanol, ascorbic acid (Rheidel-Hein), sulfuric acid $\left(\mathrm{H}_{2} \mathrm{SO}_{4}\right)$, potassium sulfate $\left(\mathrm{K}_{2} \mathrm{SO}_{4}\right)$, mercury oxide $(\mathrm{HgO})$, sodium hydroxidesodium thiosulfate $\left(\mathrm{NaOH}-\mathrm{Na}_{2} \mathrm{~S}_{2} \mathrm{O}_{3}\right)$, saturated boric acid $\left(\mathrm{H}_{3} \mathrm{BO}_{3}\right)$, hydrochloric acid $(\mathrm{HCl}) 0.02 \mathrm{~N}$, red metal indicator, and methyl blue indicator.

\subsection{Moringa leaf extraction}

Moringa leaf extraction employs the decoction method with a water solvent. The objective of this extraction is to coagulate proteins so that they are easily isolated from non-protein components. Moringa leaves were sorted, weighed and washed. A total of $100 \mathrm{~g}$ of wet Moringa leaves were mashed using a blender and added with $100 \mathrm{~mL}$ of water. The mixture was filtered using a double filter cloth to separate the fibers from the leaf pulp. The extraction process uses temperature and time based on the treatment. The mixture was then centrifuged for 20 mins to separate the supernatant and sediment. The supernatant was discarded, and the sediment was stored in the refrigerator for further analysis.

\subsection{Protein content analysis}

A standard protein curve was prepared by placing 0 (blank), $0.1 ; 0.2 ; 0.4 ; 0.6 ; 0.8$ and $1 \mathrm{~mL}$ of bovine serum albumin (BSA) into test tubes and topped up with water to $4 \mathrm{~mL}$ to make the following concentrations of $6.25 \mu \mathrm{g} /$ $\mathrm{mL}, 12.5 \mu \mathrm{g} / \mathrm{mL}, 25 \mu \mathrm{g} / \mathrm{mL}, 37.5 \mu \mathrm{g} / \mathrm{mL}, 50 \mu \mathrm{g} / \mathrm{mL}$ and $62.5 \mu \mathrm{g} / \mathrm{mL}$, respectively. Then, $5.5 \mathrm{~mL}$ of lowry reagent $\mathrm{B}$ was added into the test tube and homogenized. The mixtures were allowed to stand for $10-15$ minutes at room temperature. After that, 0.5 lowry reagent A was added into the test tubes and observed for blue color formation after 30 minutes. The solution was transferred into the cuvette and the absorbance was measured using the UV-Vis spectrophotometer.

For protein content analysis of the sample, $50 \mathrm{~g}$ of the extract was mixed with $40 \mathrm{~mL}$ of distilled water and centrifuge for 10 mins at $11,000 \mathrm{rpm}$ to obtain the protein precipitate. About $4 \mathrm{~mL}$ of the protein precipitate was taken and followed the steps for sample preparation aforementioned by replacing the BSA with the sample. The protein content was determined by measuring the absorbance of the sample and compared against the standard curve (Sulistyani and Nuril, 2017).

\subsection{Tannin content analysis}

The tannin content analysis was performed following the method of Chanwitheesuk et al. (2004) with slight modification. A total of $0.5 \mathrm{~g}$ of the extract was mixed with $10 \mathrm{~mL}$ of diethyl ether and incubated for $20 \mathrm{hrs}$. After incubation, the mixture was filtered and the resided was boiled with $100 \mathrm{~mL}$ distilled water for $2 \mathrm{hrs}$. It was then cooled and filtered. The filtrate was added with distilled water to a volume of the extract $(\sim 100 \mathrm{~mL})$ and $0.1 \mathrm{~mL}$ of the solution was added with $0.1 \mathrm{~mL}$ of Folin Ciocalteu reagent. The mixture was vortex and added with $2 \mathrm{~mL}$ of $\mathrm{Na}_{2} \mathrm{CO}_{3}$ and further vortexed to ensure a complete mix. The absorbance of the mixture was read at a wavelength of $760 \mathrm{~nm}$ after an incubation of 30 minutes at room temperature. The results were extrapolated from the standard tannic acid curve prepared following the same procedure by replacing the extract with tannic acid. The total content of tannin was expressed in mg tannic acid/kg extract (Rebaya et al., 2014).

\subsection{Antioxidant activity analysis}

The antioxidant activity test was carried out by sampling as much as $0.2 \mathrm{~mL}$ of extract and added with $3.8 \mathrm{~mL}$ of $50 \mu \mathrm{M}$ DPPH solution. Then, it was homogenized and allowed to stand for $30 \mathrm{mins}$ in the dark. The absorbance was measured at the maximum wavelength of DPPH using the UV-Vis 
spectrophotometer. The antioxidant activity of the sample by the magnitude of DPPH radical uptake resistance can be determined by calculating the percentage of DPPH absorption inhibition using the formula:

$$
\text { \%Inhibition }=\frac{\text { Abs. blank }- \text { Abs. sample }}{\text { Abs. blank }} \times 100 \%
$$

The antioxidant activity was determined using $\mathrm{IC}_{50}$ values $\left(50 \%\right.$ inhibition concentration). $\mathrm{IC}_{50}$ values of each sample concentration was calculated using the linear regression equation formula (Purwanto et al., 2017).

\subsection{Statistical analysis}

Statistical analysis was performed using MINITAB Release 14 software. Based on the analysis, the appropriate model for extraction optimization testing was obtained using Design expert 7 from graphs observed responses in the form of regression coefficients, 3D response surface plots, and contour plots.

\subsection{Optimization of extraction using the Response Surface Method (RSM).}

The experimental design to assess the total yield, total protein, antioxidant activity, and the total tannin is the Response Surface Method. The extraction process used two independent variables, namely temperature and extraction time. The composition of the temperature and time variable was designed using a centralized composite design, with the point for the temperature is $80^{\circ} \mathrm{C}$, and the point for the time variable was 10 mins. The mathematical equation model used was as follows:

$$
Y=\beta_{0}+\sum_{i=1}^{2} \beta_{i} X_{t}+\sum_{i=1}^{2} \beta_{i t} X_{t}^{2}+\sum \sum_{i<j=1}^{2} \beta_{t} X_{i} X_{i}
$$

Where $\mathrm{Y}$ is the response (outcome), $\beta_{0}$ is a constant, $\beta_{\mathrm{i}}, \beta_{\mathrm{ii}}, \beta_{\mathrm{ij}}$ are the coefficients of the independent variable $(\mathrm{X}), \mathrm{X}$ is the independent variable with no code (for the extraction temperature variable: extraction temperature $\left(\mathrm{X}_{1}\right)$ level 70,80 and $90^{\circ} \mathrm{C}$; extraction time $\left(\mathrm{X}_{2}\right)$ level 5, 10 and 15 mins and $\varepsilon$ is random error. The level of the independent variables (temperature and time) in this study can be seen in Table 1 (Bharathi and Rajendiran 2011).

Table 1. Level of independent variables, code, and optimized values

\begin{tabular}{llcccc}
\hline \multicolumn{1}{c}{ Independent } & Degree & -1 & 1 & $-\alpha$ & $+\alpha$ \\
\hline Temperature $\left(\mathrm{X}_{1}\right)$ & Celsius & 70 & 90 & 65,85 & 94,14 \\
Time $\left(\mathrm{X}_{2}\right)$ & Minute & 5 & 15 & 2.93 & 17.07 \\
\hline
\end{tabular}

\section{Results and discussion}

Based on the results, the actual values, responses of protein variable, antioxidant activity $\left(\mathrm{IC}_{50}\right)$, and tannins are tabulated in Table 2.

Based on Table 2, protein values ranged from $11.12 \%$ at $65.86^{\circ} \mathrm{C}$ with extraction time of $10 \mathrm{mins}$ to $19.6 \%$ at $80^{\circ} \mathrm{C}$ with 17.07 mins of extraction time. The antioxidant activity $\left(\mathrm{IC}_{50}\right)$ was between $9.23 \mu \mathrm{g} / \mathrm{mL}$ at $80^{\circ} \mathrm{C}$ with extraction time of $10 \mathrm{mins}$ to $13.32 \mu \mathrm{g} / \mathrm{mL}$ at $90^{\circ} \mathrm{C}$ with extraction time of 15 mins. While tannin values ranged from $7.13 \%$ at $80^{\circ} \mathrm{C}$ with extraction time of 17.07 mins to $13.71 \%$ at $65.86^{\circ} \mathrm{C}$ with extraction time of 10 mins. The responses of the total protein variable, antioxidant activity $\left(\mathrm{IC}_{50}\right)$, and total tannin are explained below.

\subsection{Total protein}

Moringa leaf is one of the parts of moringa plants that have several benefits and usage. This is because moringa leaves are rich in nutrients, including protein, calcium, iron, vitamin $\mathrm{A}$, vitamin $\mathrm{B}$, and vitamin $\mathrm{C}$ (Misra et al., 2014). Besides, moringa leaves are a potential source of protein to overcome the problem of malnutrition (Farooq et al., 2012). The results of the analysis using the response surface method (RSM), obtained from the selection of models based on "Sequential Model Sum of Squares", the selected model is a quadratic because it has a value of $0.0144(<5 \%)$. The probability of model error was less than $5 \%$, so it has a significant effect on the total protein response. Likewise, with the Lack of Fit calculation results, the quadratic model was stated as the "suggested" model.

Based on the analysis of R-square/ $\mathrm{R}^{2}$ (coefficient of determination) on ANOVA, it has a $\mathrm{R}^{2}$ value of 0.8169 . This reveals that the data is capable to support the model of $81.69 \%$ in which consists of extraction temperature and extraction time. The remaining $18.31 \%$ is influenced by other factors that are not included in the model such as the type of solvent, the extraction method, plant varieties, and the growing environment of the plant itself and others (Hernández et al., 2009). The effect of temperature and extraction time on total protein are shown in Figures 1a and 1b.

Figure 1 shows the amount of protein due to the effect of variations in temperature and extraction time. The temperature and extraction time variable values are set to the optimum value at running \# 13 RSM experimental design. The lines consisting of points on the contour plot graph that show a combination of two components with different amounts that produce the same protein response value (Myers et al., 1995).

Figure $1 \mathrm{a}$ and $1 \mathrm{~b}$ reveal that the $\mathrm{x}$-axis is the extraction temperature factor and the $y$-axis is the extraction time factor. The line inside the contour plot is 
Table 2. Total protein values, antioxidant activity $\left(\mathrm{IC}_{50}\right)$, and tannin extract of Moringa leaf

\begin{tabular}{ccccc}
\hline Extraction Temperature $\left({ }^{\circ} \mathrm{C}\right)$ & Extraction Time $(\mathrm{min})$ & Protein $(\%)$ & Antioxidant $\mathrm{IC}_{50}(\mathrm{mg} / \mathrm{mL})$ & Tannin $(\%)$ \\
\hline 80 & 10 & 17.83 & 10.03 & 8.27 \\
70 & 5 & 11.32 & 13.3 & 12.5 \\
94.14 & 10 & 13.35 & 12.5 & 11.95 \\
80 & 10 & 16.21 & 10.63 & 7.22 \\
80 & 17.07 & 19.6 & 10.89 & 7.13 \\
80 & 10 & 16.89 & 10.33 & 8.07 \\
70 & 15 & 12.98 & 12.9 & 8.87 \\
80 & 10 & 16.09 & 10.23 & 9.06 \\
90 & 15 & 15.67 & 13.32 & 11.55 \\
90 & 5 & 16.08 & 10.84 & 11.2 \\
80 & 10 & 17.23 & 9.23 & 8.09 \\
80 & 2.93 & 11.95 & 12.23 & 13.05 \\
65.86 & 10 & 11.12 & & 9.21 \\
\hline
\end{tabular}
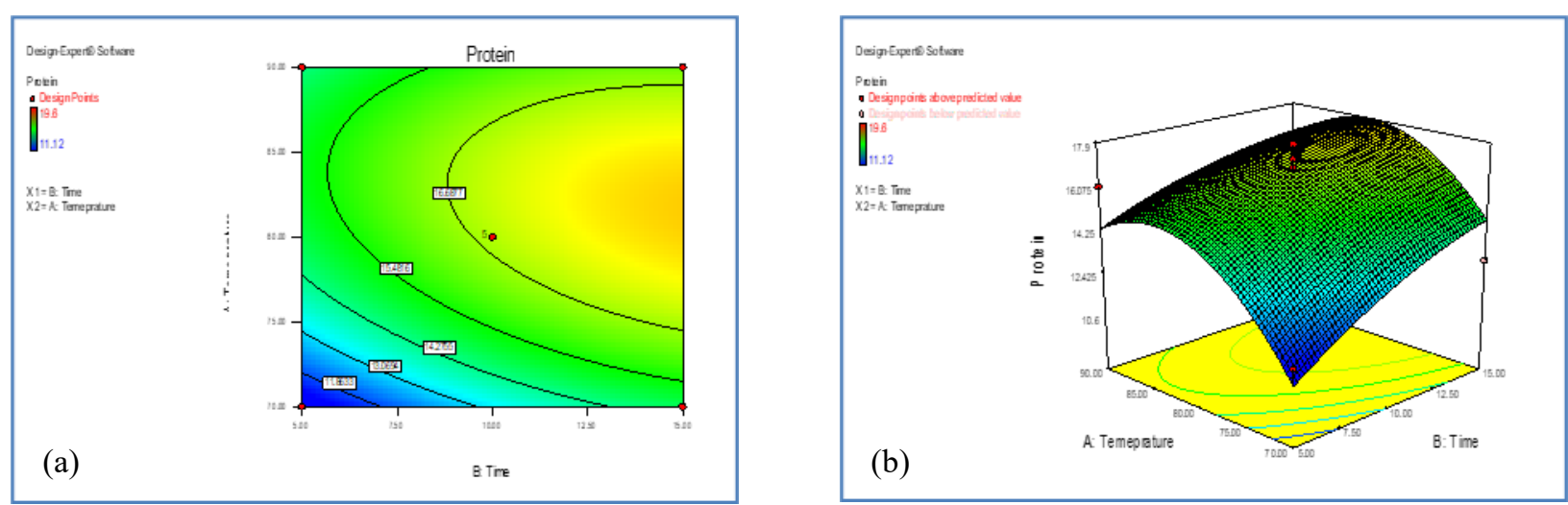

Figure 1. (a). Contour plot and (b) Surface response that shows the effect of temperature and extraction time on the total protein of Moringa leaf extract

the protein response value. Judging by the contour color, the red dot shows the highest protein response value of $19.6 \%$. The blue color indicates the lowest response value of $11.12 \%$. Based on Figure 1, it can be seen that a variation in temperature and extraction time significantly affects the total protein response. The total protein content increased along with the increase of extraction temperature. However, the total protein content decreased after the extraction temperature was above $80^{\circ} \mathrm{C}$. The lowest total protein content was at the extraction temperature of $65.85^{\circ} \mathrm{C}$ at $11.12 \%$. The protein content increased along with the increase of the extraction temperature up to the highest level of $19.6 \%$ at $80^{\circ} \mathrm{C}$, and then the protein content decreased after the temperature was more than $80^{\circ} \mathrm{C}$

Temperature is one of the important factors that play a role in the quality and levels of protein. The increase of extraction temperature can increase the solubility of the protein in the extract. But the higher the temperature, the higher the protein damage which also affects the quality of the protein (Conscience, 2016).

Moreover, the total protein content was observed to be affected by the extraction time and in a proportional sequence. The protein level was higher with a longer extraction time. However, the protein level decreased after passing an optimum time. Diantika et al. (2014) stated that a long extraction time can cause a long heating effect on the material so that the results will increase the saturation point. Jayanudin et al. (2014) also added that this heating effect will enlarge the pores of the material so that the solvent can enter through the pores and dissolve the components that are absorbed then, the solute diffuses out the cell wall surface.

Considering trends in the curve, it shows that the higher the extraction temperature and the longer the extraction time, the protein value increases and will decrease again after reaching a certain time and temperature. This is consistent with the opinion of Ahmed (2016) that heating for coagulation of protein concentrates from leafy vegetables is applied at a temperature of $80-90^{\circ} \mathrm{C}$. Meanwhile, according to Purwitasari et al. (2014), the protein content of the product raises with a long extraction time. And then, it becomes saturated or damaged because more protein is dissolved in the solvent to a certain extent.

\subsection{Antioxidant activity $\left(I C_{50}\right)$}

Antioxidants are bioactive compounds that can inhibit free radicals and substrate oxidation, which have an important role in protecting cells from damage by being able to block the process of oxidative damage 
caused by free radicals (Huang et al., 2010). Plants are potent sources of natural antioxidants. Phytochemical compounds found in plants such as flavonoids, phenolic acids, tannins, terpenoids, and alkaloids with a significant antioxidant activity which is very good for maintaining health (Winarsi, 2007).

The model selection results are based on "Sequential Model Sum of Squares", the selected model is quadratic because it has a value of $0.002(<5 \%)$. This shows that the chance of model error is less than $5 \%$, so it has a significant effect on the response of antioxidant activity. Likewise, with the Lack of Fit calculation results, the quadratic model was stated as "suggested", namely the chosen model. While the $\mathrm{R}$-square/ $\mathrm{R}^{2}$ (coefficient of determination) on ANOVA has a value of 0.8501 , this shows the data can support the model of $85.01 \%$ in which consists of the treatment of extraction temperature and extraction time. The remaining $14.9 \%$ is influenced by other factors that are not included in the model. The effect of temperature and extraction time on the antioxidant activity is presented in Figure 2.

Based on the research results, the extraction temperature has a significant effect on the model. In Figure 2, it can be seen that the antioxidant activity $\left(\mathrm{IC}_{50}\right)$ will decrease along with the increase of extraction temperature. But the antioxidant activity $\left(\mathrm{IC}_{50}\right)$ increased at the extraction temperatures above $80^{\circ} \mathrm{C}$. Likewise, with the extraction time treatment, the graph clearly shows that antioxidant activity $\left(\mathrm{IC}_{50}\right)$ will increase after the extraction time of 10 minutes.

In Figure 2, the red color shows the highest antioxidant response value of $13.32 \mathrm{mg} / \mathrm{mL}$. The blue color indicates the lowest response value of $9.23 \mathrm{mg} / \mathrm{mL}$. Considering the trends in the curve, it shows that the higher the temperature and time increase, the antioxidant value decreases and then rises after passing through the critical point. According to Belyagoubi et al. (2016) temperature is a very important parameter in the food

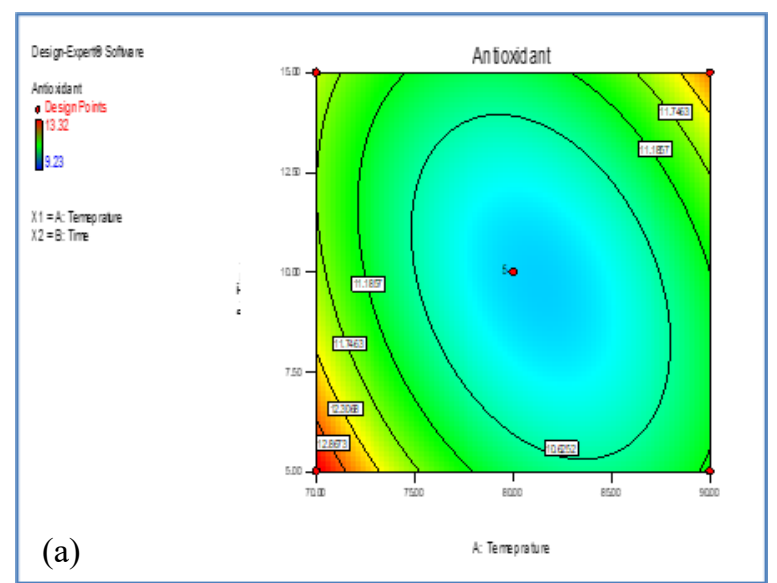

industry related to the processing, extraction, and storage of food ingredients. The $\mathrm{IC}_{50}$ antioxidant activity value based on the results of the analysis using DPPH reagents ranged from $9.23 \mathrm{mg} / \mathrm{mL}$ to $13.32 \mathrm{mg} / \mathrm{mL}$. This shows that the antioxidant value $\left(\mathrm{IC}_{50}\right)$ in moringa leaf extract for all treatment variations is in the very strong antioxidant group, $<50 \mathrm{mg} / \mathrm{mL}$.

\subsection{Total tannin}

Tannin is a very complex organic compound and can be found in various plants. Tannins can bind to proteins so that proteins in plants can be resistant to degradation by protease enzymes in plants (Dewi et al., 2019). Tannins are chemical compounds that are classified as polyphenol compounds (Deaville et al., 2010). Desmiaty et al. (2008) explain that tannins are very complex organic substances, which are composed of phenolic compounds which are difficult to separate and function as natural antioxidants.

Based on the analysis results, the model selection is based on the "Sequential Model Sum of Squares", the selected model is quadratic because it has a value of $0.0002(<5 \%)$. This shows that the chance of model error is less than $5 \%$, so it has a significant effect on the response of antioxidant activity. Likewise, with the Lack of Fit calculation results, the quadratic model is stated as "suggested", namely the chosen model. While R-square/ $\mathrm{R}^{2}$ (coefficient of determination) on ANOVA has a value of 0.9256 , this shows the data can support a model of $92.56 \%$ in which consists of the treatment of extraction temperature and extraction time. The remaining $7.44 \%$ is influenced by other factors that are not included in the model. The effect of temperature and extraction time on the total tannin content is presented in Figure 3.

Figure 3 shows that the treatment of temperature variations decreases the tannin extract. However, it is stable and tends to rise again after passing its optimum temperature. While the effect of extraction time decreases the amount of tannin along with the addition of

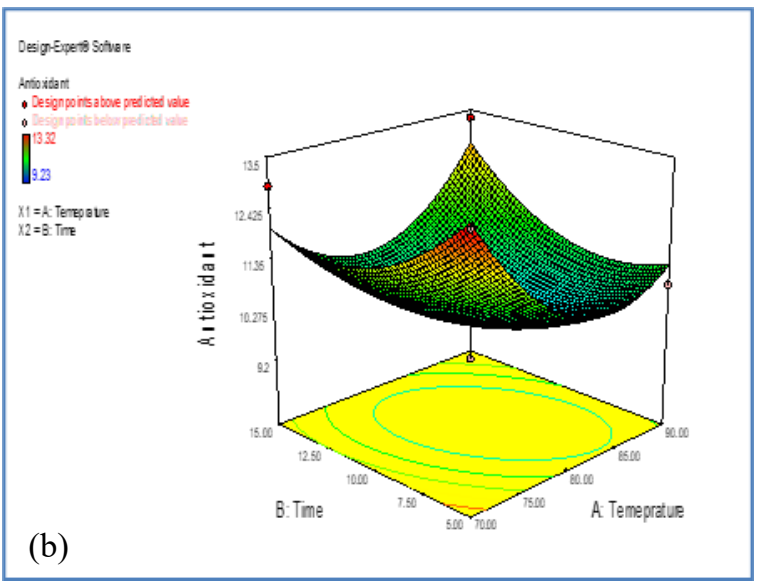

Figure 2. (a). Contour plot and (b) Surface response that shows the effect of temperature and extraction time on the antioxidant activity of Moringa leaf extract 

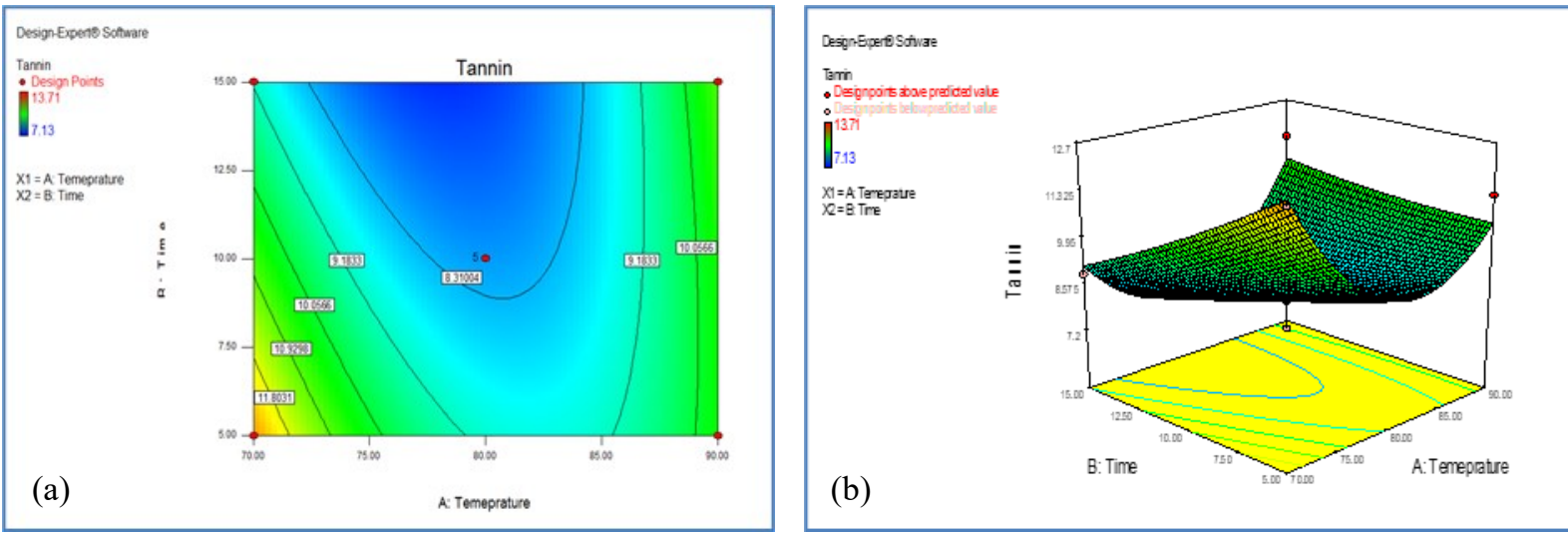

Figure 3. (a) Contour plot, (b) Surface response showing the effect of temperature and extraction time on total tannin in Moringa leaf extract

extraction time. This happens because the longer the extraction process, the tannin compounds contained in moringa leaves undergo an enzymatic oxidation reaction, while the increase in tannin levels occurs due to the inactivation of the catechol oxidase enzyme at higher temperatures (Purnama et al., 2015).

Based on the analysis results, it is reported that the critical value is $80^{\circ} \mathrm{C}$ and 10 mins. At that point, the total tannin is predicted to reach $8.07 \%$. However, at temperatures above $80^{\circ} \mathrm{C}$, the tannin level increased again. This is because the phenol level is disturbed due to the high temperature in the extraction process. In this study, tannin levels will be better when acquiring fewer tannins. This is due to the nature of tannin as an antinutrient compound.

Tannin is known as an anti-nutrient compound because of their ability to form complex bonds with proteins. The ability of tannins to precipitate these proteins because tannin has several functional groups that can form strong complexes with protein molecules, therefore tannin is generally regarded as detrimental antinutrients. The bond between tannin and protein is so strong that protein cannot be digested by the digestive tract (Matteo et al., 2010).

\subsection{Response optimization}

Based on the calculation, optimization results using

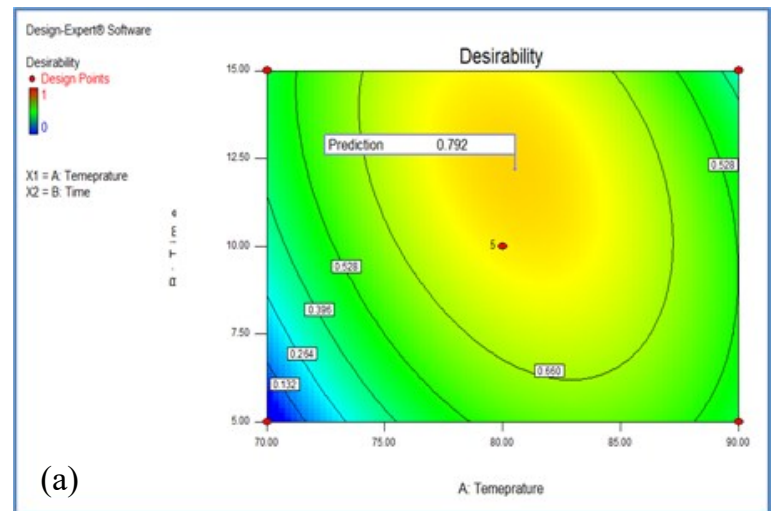

Design Expert Ver. 9 Trial show that the optimal conditions of the moringa leaf extraction process are the extraction temperature of $80.54^{\circ} \mathrm{C}$ with extraction time of 12.19 minutes. The treatment resulted in a prediction of a total protein response of $17.4594 \%$, and antioxidant activity of $10.2629 \mathrm{mg} / \mathrm{mL}$, and tannin 7,853 with the desirability of 0.792 or $79.2 \%$. The contour plots and response surface of the predicted results are presented in Figure 4.

According to Bezzera et al. (2008), desirability shows the desired scale for each response and determines the accuracy degree of the optimal solution. The desirability value in this study is 0.792 or $79.2 \%$, where the value is getting closer to the value of 1 , the accuracy is higher. The scale range for desirability value is 0 to 1 , where a value of 0 indicates an unwanted response, while a value of 1 indicates a fully desirable response.

The results of the research on total protein and tannin parameters have the opposite graph trend, where the higher temperature treatment and the longer extraction time will increase the amount of protein, but the amount of protein will decrease again along with the increase in temperature and extraction time. This is contrary to the amount of tannin where tannin will decrease along with the increase in temperature and extraction time, but the tannin value will rise again after passing the optimum point. This is consistent with the statement of Purwitasari

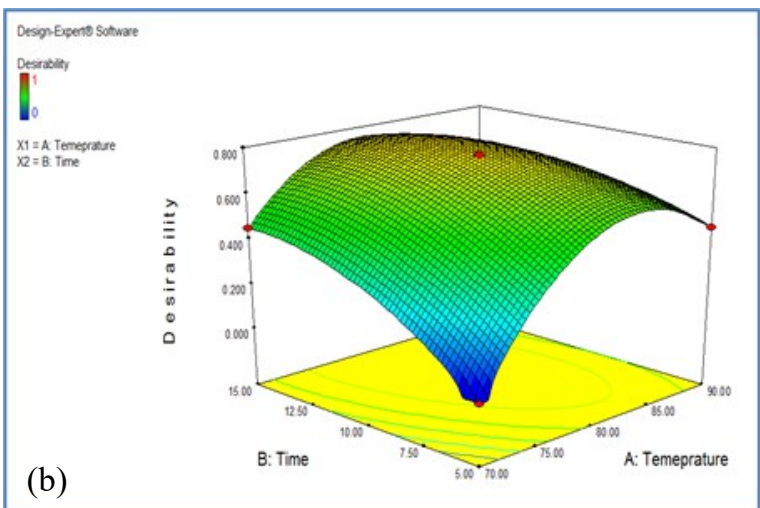

Figure 3. (a) Contour plot, (b) Surface response showing the effect of temperature and extraction time on total tannin in Moringa leaf extract 
et al. (2004) that the protein content of the product rises with longer extraction time, and then it will decrease to a certain extent because more protein is dissolved in the solvent and becomes saturated or damaged. Although the protein and tannin parameters show the opposite results, the two have a close relationship. As Makkar (1993) stated that the presence of several functional groups in tannins will cause protein deposition when the amount of tannin increases and vice versa. Besides, tannins also bind to mucosal proteins that they affect the absorption of nutrients. In general, tannins are considered as harmful anti-nutrients. Besides, the presence of tannin in moringa leaf extracts must also be minimized, this is to reduce the taste of bit or chelate in the final product.

The effect of temperature and extraction time does not only occur on the amount of protein and tannin, but also the antioxidant activity. Antioxidant activity will decrease when the extraction temperature is above $80^{\circ} \mathrm{C}$ and the extraction time is more than 10 mins. Prolonged extraction time and higher temperatures will cause oxidation of bioactive compounds and antioxidant activity (Chew et al., 2011). Based on the results of the study, the decoc extraction technique using water as the solvent has a significant effect on the amount of tannin, protein, and the antioxidant activity. Besides, the extraction method using water as the solvent has the prospect of being developed further on a larger scale, because the technique is simple, safe, and easy to apply when compared to the other methods (Vongsak et al., 2013).

\section{Conclusion}

RSM is an appropriate and effective method for optimizing the extraction conditions of moringa leaves using a water solvent. The optimum condition for maintaining the amount of protein and antioxidant activity and reducing tannin content in moringa leaf extract is at an extraction temperature of $80.54^{\circ} \mathrm{C}$ with an extraction time of 12.19 mins. It can be predicted that the extract will contain $17.4594 \%$ of total protein, 10.2629 $\mu \mathrm{g} / \mathrm{mL}$ of antioxidant activity and 7,853 tannin.

\section{Conflict of interest}

The authors declare no conflict of interest.

\section{Acknowledgement}

Thank you to the promoters and co-promoters, all lecturers, staff, and laboratory staff at the Faculty of Agricultural Technology, Universitas Brawijaya and Faculty of Agriculture, Yudharta University who have helped in the research and preparation of this scientific article. Also, thank you to the LPDP for funding this research.

\section{References}

Bharathi, J.P. and Rajendiran, R. (2011). Optimization of Extraction of Phenolic Compounds from Avicennia marina (Forssk.) Vierh using Response Surface Methodology. World Academy of Science and Engineering Technology, 56, 1191-1195.

Chanwitheesuk, A., Teerawutgulrag A. and Rakariyatham N. (2004). Screening of Antioxidant Activity and Antioxidant Compounds of Some Edible Plants of Thailand. Food Chemistry, 92(3), 491-497. https://doi.org/10.1016/ j.foodchem.2004.07.035

Chew, Ng, Thoo, K. and Wan, Ho. (2011). Effect of Ethanol Concentration, Extraction Time and Extraction Temperature on The Recovery of Phenolic Compounds and Antioxidant Capacity of Centella asiatica extracts. International Food Research Journal, 18, 571-578.

Chumark, P., Khunawat, P., Sanvarinda, Y., Phornchirasilp, S., Morales, N.P., Phivthong-ngam, L. and Klai-upsorn, S.P. (2008). The in vitro and ex vivo antioxidant properties, hypolipidaemic and antiatherosclerotic activities of water extract of Moringa oleifera Lam. leaves. Journal of Ethnopharmacology, 116(3), 439-446. https:// doi.org/10.1016/j.jep.2007.12.010

Das, A.K., Rajkumar, V., Verma, A.K. and Swarup, D. (2012). Moringa oleiferia leaves extract: a natural antioxidant for retarding lipid peroxidation in cooked goat meat patties. International Journal of Food Science and Technology, 47(3), 585-591. https:// doi.org/10.1111/j.1365-2621.2011.02881.x

Deaville, E.R., Givens, D.I. and Mueller-Harvey, I. (2010). Chesnut and Mimosa tannin silages: Effect in sheep differ for apparent digestibilty, nitrogen utilitation and losses. Animal Feed Science and Technology, 157(3-4), 129-138. https:// doi.org/10.1016/j.anifeedsci.2010.02.007

Desmiaty, Y., Ratih, H., Dewi, M.A. and Agustin, R. (2008). Penentuan jumLah tanin total pada daun jati belanda (Guazuma ulmifolia Lamk) dan Daun Sambang Darah (Excoecaria bicolor Hassk.) Secara Kolorimetri dengan Pereaksi Biru Prusia. Ortocarpus, 8, 106-109.

Dewi, A.L., Siregar, V.D. and Kusumayanti, H. (2019). Effect of extraction time on tannin antioxidant level and flavonoid on pandan wangi leaf (Pandanusamaryllifolius Roxb) using hydrothermal extractor. Journal of Physics: Conference Series, 1295, 012066. https://doi.org/10.1088/1742- 


\section{6/1295/1/012066}

Diantika, Sandra, Malin and Rini, Y. (2014). Pengaruh lama ekstraksi dan konsentrasi pelarut etanol terhadap ekstraksi antioksidan biji kakao (Theobroma cacao L.). Jurnal Teknologi Pertanian, 15, 159-164. [In Bahasa Indonesia]. https:// doi.org/10.21776/ub.jtp.2014.015.03.02

Farooq, F., Rai, M., Tiwari, A., Khan, A. A. and Farooq, S. (2012). Medicinal properties of Moringa oleifera: An overview of promising healer. Journal of Medicinal Plants Research, 6(27), 4368-4374. https://doi.org/10.5897/JMPR012.279

Gopalakrishnan, L., Doriya, K. and Kumar, D.S. (2016). Moringa oleifera: A review on nutritive importance and its medicinal application. Food Science and Human Wellness, 5(2), 49-56. https:// doi.org/10.1016/j.fshw.2016.04.001

Hernández, Y., Lobo, M.G. and González, M. (2009). Factors affecting sample extraction in the liquid chromatographic determination of organic acids in papaya and pineapple. Food Chemistry, 114(2), 734741. https://doi.org/10.1016/j.foodchem.2008.10.021

Huang, C. and Corke, S. (2010). Survey of Antioxidant Capacity and Nutritional Quality of Selected Edible and Medicinal Fruit Plants in Hong Kong. Journal Food Compos Analysis, 23(6), 510-517. https:// doi.org/10.1016/j.jfca.2009.12.006

Kholis, N. and Hadi, F. (2010). Pengujian bioassay biskuit balita yang disuplementasi konsentrat protein daun kelor (Moringa oleifera) pada model tikus malnutrisi. Jurnal Teknologi Pertanian, 11(3), 144151

Mahmood, K.T., Mugal, T. and Haq, I.U. (2010). Moringa oleifera: a natural gift-A review. Journal of Pharmaceutical Sciences and Research, 2(11), 775.

Makkar. (1993). Gravimertric determination of tannins and their correlation with chemical nd protein precipitation methods. Journal of The Science of Food and Agriculutre, 61(2), 161-165. https:// doi.org/10.1002/jsfa.2740610205

Matteo, D., Adriana, S., Milena, A., Mario, P., Massimo, D. and Amalia, B. (2010). The ascorbic acid content of tomato fruits isassociated with the expression of genes involvedin pectin degradation. Plant Biology, 10, 163. https://doi.org/10.1186/1471-2229-10-163

Mendieta-Araica, B., Spörndly, E., Reyes- Sánchez, N., Salmerón-Miranda, F. and Halling, M. (2013). Biomass production and chemical composition of Moringa oleifera under different planting densities and levels of nitrogen fertilization. Agroforestry Systems, 87, 81-92. https://doi.org/10.1007/s10457012-9525-5
Misra, A., Srivastava, S. and Srivastava, M. (2014). Evaluation of anti diarrheal potential of Moringa oleifera (Lam.) leaves. Journal of Pharmacognosy and Phytochemistry, 2(5), 43-46

Moyo, B., Oyedemi, S., Masika, P.J. and Muchenje, V. (2012). Polyphenolic content and antioxidant properties of Moringa oleifera leaf extracts and enzymatic activity of liver from goats supplemented with Moringa oleifera leaves/sunflower seed cake. Meat Science, 91(4), 441-447. https:// doi.org/10.1016/j.meatsci.2012.02.029

Ogbe, A.O. and Affiku, J.P. (2011). Proximate study, mineral and anti-nutrient composition of Moringa oleifera leaves harvested from Lafia, Nigeria: potential benefits in poultry nutrition and health. The Journal of Microbiology, Biotechnology and Food Sciences, 1(3), 296.

Purnama, I., Jajang, G. and Kusmayadi, S., (2019). Pengaruh lama waktu dan suhu ekstraksi terhadap kandungan tanin limbah daun teh hijau tua (Camellia sinensis). Jurnal Teknik Kimia, 6(2). [In Bahasa Indonesia]. https://doi.org/10.26555/ chemica.v6i2.14724

Purwanto, D., Syaiful, B. and Ahmad, R. (2017). Uji aktivitas antioksidan ekstrak buah purnajiwa (Kopsia arborea Blume.) dengan berbagai pelarut. Kovalen, 3(1), 24 - 32. [In Bahasa Indonesia]. https:// doi.org/10.22487/j24775398.2017.v3.i1.8230

Purwitasari, A., Hendrawan, Y. and Yulianingsih, R. (2014). Pengaruh suhu dan waktu ekstraksi terhadap sifat fisik kimia dalam pembuatan konsentrat protein kacang komak (Lablab purpureus (L.) sweet). Jurnal Bioproses Komoditas Tropis, 2, 42-53. [In Bahasa Indonesia].

Rebaya, A., Souad, I.B., Béatrice, B., Valérie, M.L., Fathi, M., Evelyne, O., Jamila, K.C. and Malika, T.A. (2014). Total phenolic, total flavonoid, tannin content, and antioxidant capacity of Halimium halimifolium (Cistaceae). Journal of Applied Pharmaceutical Science, 5(1), 052-057.

Shahriar, M., Hossain, M.I., Bahar, A.N.M., Akhter, S., Haque, M.A. and Bhuiyan, M.A. (2012). Preliminary phytochemical screening, in-vitro antioxidant and cytotoxic activity of five different extracts of Moringa oleifera leaf. Journal of Applied Pharmaceutical Science, 2(5), 65. https:// doi.org/10.7324/JAPS.2012.2510

Sulistyani, M. and Nuril, H. (2017). Optimasi pengukuran ppektrum vibrasi sample protein menggunakan spektrofotometer fourier transform infrared (FT-IR). Indonesian Journal of Chemical Science, 6(2), 174. 
Upadhye, K., Rangari, V. and Mathur, V. (2011). Evaluation of antinociceptive activities of fresh leaf juice and ethanolic extract of Moringa oliefera Lamm. Asian Journal of Pharmacy and Clinical Research, 4, 114-116

Vongsak, B., Pongtip, S., Supachoke, Suchitra, T., Yuvadee, W. and Wandee, G. (2013). Maximizing total phenolics, total flavonoids contents and antioxidant activity of Moringa oleifera leaf extract by the appropriate extraction method. Industrial Crops and Products, 44, 566- 571. https:// doi.org/10.1016/j.indcrop.2012.09.021

Wangcharoen, W. and Gomolmanee, S. (2011). Antioxidant capacity and total phenolic content of Moringa oleifera grown in Chiang Mai, Thailand. Thai Journal of Agricultural Science, 44 (5), 118-124

Winarsi, H.M.S. (2007). Antioksidan Alami dan Radikal Bebas. Yogyakarta, Indonesia: Kansius. [In Bahasa Indonesia].

Yameogo, C.W., Bengaly, M.D., Savadogo, A., Nikiema, P.A. and Traore, S.A. (2011). Determination of chemical composition and nutritional values of Moringa oleifera leaves. Pakistan Journal of Nutrition, 10(3), 264268. https://doi.org/10.3923/pjn.2011.264.268 